\title{
The Tyranny of the Pearl: Desire, Oppression, and Nostalgia in the Lower Gulf
}

\author{
Victoria Penziner Hightower
}

Objects exist within a dialogue between the thingin-itself and the thing-as-used. ${ }^{1}$ Within heritage studies, there is also the idea of the thing-asremembered. In the United Arab Emirates (U.A.E.), the pearl is an object that enables a productive discussion of these meanings and connections. ${ }^{2}$ The pearl brings feeling, thought, lived experience, and memory together ${ }^{3}$ and, as such, it helps to put the past and present into dialogue within the U.A.E. today. A pearl's value also lies in its ability to be traded away. Therefore, a pearl epitomizes Daniel Miller's description of material culture, which acknowledges that objects can be peripheral to human needs, yet still influence behavior and identity formation. ${ }^{4}$ The relationship between the thingin-itself, -as-used, and -as-remembered helps to

1 Ralph Blumenau, "Kant and the Thing in Itself," Philosophy Now 31 (2001): 18-21.

2 Robert Saint George, "Material Culture in Folklife Studies," in The Oxford Handbook of Material Culture Studies, ed. Dan Hicks and Mary C. Beaudry (Oxford: Oxford University Press, 2010), 123-49.

3 Sherry Turkle, "Introduction: The Things That Matter," in Evocative Objects: Things We Think With, ed. Sherry Turkle (Cambridge, MA: MIT Press, 2011), 9.

4 Challenging Marxist materialism, according to which objects shape reality, and more functionalist understandings of material culture, according to which culture shapes materials, Miller argues for a dialectical relationship of meaning making between things and people. He argues that "stuff" has cultural and social meanings that vary over time and space and that these meanings are constantly negotiated. If, then, as Miller suggests, "stuff" has social and cultural meanings, it stands to reason that these meanings do not necessarily need to be constructed as wholly positive or negative; instead, they can have a complex, changing, and evolving nature over time, which incorporates both expose how this tiny, beautiful luxury object could paradoxically imply an element of tyranny for those who toiled to extract them and how that oppression could be rehabilitated through the process of memory creation.

Although Immanuel Kant applied his notion of thinghood to cognition, it is possible to extend it to other areas of knowledge as well to help historians and scholars make sense of the contradictions inherent in the ways that people have used, valued, and remembered pearls. ${ }^{5}$ The pearl's narrative of suffering stands in stark contrast to the traditional idea of the pearl as a luxury good. This latter narrative considers the item's wealth, beauty, or fineness. This dual nature of the pearl within the discourse of the history of the lower Gulf emirates suggests that this object has undergone a rhetorical rehabilitation. In order to understand how and why this happened, it is important to understand the different ways the pearl functioned as a material object in this area.

The Pearl as Itself

Kant's idea of the thing-in-itself grows from observed phenomena. For Kant, these phenomena are perceived through human senses. Therefore, objects gain primary meaning through the way that humans observe and perceive them. For the

the notions of luxury and tyranny. See Daniel Miller, Stuff (Cambridge: Polity Press, 2010), 51.

5 Immanuel Kant, Critique of Pure Reason, trans. and ed. Paul Guyer and Allen W. Wood (Cambridge: Cambridge University Press, 1998), 149. 
pearl, this raises some important contradictions. The mollusks that produce pearls are easy to catch, being immobile on the sea floor, but the animal's body is covered by a hard shell and looks only slightly different from other nearby objects, making it challenging to distinguish and painful to pry away from the coral and rocks on the bottom of the ocean. Furthermore, there is no external indication on the animal that it is carrying a pearl. The difficulties of acquiring this object are nevertheless balanced by its beauty and ease of manufacturing. Pearls are beautiful objects. They come in a variety of colors and their luster is transfixing. They are relatively easy to manufacture into jewelry and do not require faceting or polishing; rather, they can be simply glued to a setting or drilled and strung into jewelry. This object is prized but also unforgivingly fragile-capable of being crushed or having its much-valued luster rubbed off by something as innocuous as contact with human body oils. Its fragility contributes to its luxury status.

Historically, pearls were sought after and traded throughout the world with accounts of them entering the European market regularly dating from the Roman period. ${ }^{6}$ Robert Carter has chronicled extensively the historical evidence for pearls in the Gulf area stretching to the second millennium B.c. and provided a series of maps that illustrate the location of the beds in the Gulf over time. ${ }^{7}$ Leaning on R.A. Donkin's chronicle of pearl fishing, Carter charts the historical evidence for pearling through the fourth/third century to the first century B.C., finding references to their trade and use in late Roman and Byzantine texts, as well as in

6 R.A. Donkin, Beyond Price: Pearls and Pearl-Fishing: Origins to the Age of Discoveries (Philadelphia: American Philosophical Society, 1998); Robert Carter, Sea of Pearls: Seven Thousand Years of the Industry that Shaped the Gulf (London: Arabian Publishing, 2012), 3-29. in the Persian Gulf," Journal of the Economic and Social History of the Orient 48, no. 2 (2005): 14; Carter, Sea of Pearls, 64, 108, 114, and 116.

early Islamic, Talmudic, and Nestorian writings. ${ }^{8}$ During the Islamic period, the trade in pearls increased and references to this occupation became more substantive after the tenth century C.E. ${ }^{9} \mathrm{Ibn}$ Battuta journeyed through the Gulf and observed diving first hand, as did the geographer Al-Idrisi. ${ }^{10}$ Europeans such as the Portuguese Duarte Barbosa and Pedro Teixeira and the Italian Gasparo Balbi made reference to the pearling centers in Julfar, Bahrain, Hormuz, and Qatif."1 Writing in the fifteenth century, Gonzalez de Clavijo suggested that most of Spain's pearls originated in Hormuz. ${ }^{12}$ During the seventeenth and eighteenth centuries, with the establishment of more direct and regular trade through the East India Companies and due to a stronger European presence in the Gulf area, the European documentary evidence of pearling increased. Citing J.A. Saldanha, who compiled a precis of British references, Carter indicates that pearls were first recorded in 1675 by an East India Company captain who noted the richness of pearl fishing in the region and mentioned that the Dutch had sent three missions to Bahrain to investigate whether they should be trading in pearls as well. ${ }^{13}$ After some political instability in the seventeenth and early eighteenth centuries, the Gulf pearl fisheries became a substantial source of income for many along the Persian and Arab coasts of the Gulf. However, by 1877 , the British officials noted that there was no way to estimate the number of pearls changing hands or being extracted from the Gulf, nor could they do more than record a small fraction of these transactions. ${ }^{14}$ Pearls were simply too easy to conceal.

\footnotetext{
8 Carter, Sea of Pearls, 144.

9 Ibid.

10 Ibid., 145 .

11 Ibid., 146.

12 Ibid., 123, 135.

13 Ibid., 149-50.

14 E.L. Durand, "Appendix A: Notes on the Pearl Fisheries of the Persian Gulf," in Records of the Persian Gulf Pearl Fisheries 1857-1962, Volume 1: 1857-1914, ed. Anita L.P. Burdett (Gerrard's Cross: Archive Editions, 1995), 74.
} 
A pearl is formed when an irritant enters the body of a mollusk. In the Arabian Gulf, the most common species in which this happens are Pinctada radiata, Pinctada margaritafera, and Pteria avicular. Of these three species, Pinctada radia$t a$ is the most common in terms of the animal's distribution and its regular production of pearls. Mollusks are soft-bodied creatures, so even something as innocuous as a piece of sand can have devastating effects on them because of the sand's sharp edges. The animal secretes nacre, the same substance from which mother-of-pearl is created, to coat the irritant and smooth out its edges.

Because the primary purpose of making the pearl for the animal is to smooth out the rough edges of the irritant, pearls occur in a variety of shapes and sizes. The most sought after are spherical, white, and highly lustrous, but they can come in colors ranging from white to off-white, yellow, blue, green, and, rarely, almost purple-black. They can be large or very small. Pearls from the Arabian Gulf were most often quite small, that is why they were designated seed pearls. In a report from 1877 , a British official estimated that only two large pearls were found in the entirety of the Gulf during any given diving season. ${ }^{15}$ In terms of shape, they can be spherical or oblong, depending on the shape of the irritant. Luster is probably the most important quality of the larger pearls. It is the shininess and the way that the light reflects off the pearls that make them so beautiful and attractive. ${ }^{16}$

\footnotetext{
15 Ibid., 72.

16 Carter has a useful appendix that shows the various size designations throughout the Gulf; for details, see Sea of Pearls, 287-308. For more U.A.E.-specific designations, see Mouza Al Hamour, Min Adab al Ghaws bimintaqa al Khaleej al Arabi [Diving literature in the Arabian Gulf] (Sharjah: Nadi al Muntaza al Fatayat, 1990), 15-17; and Mustafa 'Azzat Hibra, Mosu'a al Ghaws wa al Lu'lu'fi Mujtam'a al Imarat wa al Khaleej al 'Arabi Qabl al Naft [The encyclopedia of diving and pearls in Emirates society and the Arabian Gulf before oil] (Ras al Khaimah: Markaz al Dirasat wa al Watha'iq, 2004), 128-40.
}

The pearl as a thing-in-itself would be insignificant if not for the divers who extracted it from the mollusk's body. For them, this object was important because it could be acquired. Pearl diving occurred during the summer. The season lasted from three to six months, depending on weather, the timing of Ramadan, and the quality of the pearls extracted. The weather was hot and humid, the days were long, and the life on a pearl boat was difficult. Boat crews contended with high temperatures, well over $100 \mathrm{~F} / 37 \mathrm{C}$, and humidity approaching $100 \%$. On the boats, there was no shade. The Gulf is highly saline and because fresh water was precious, little was wasted for washing the salt off the divers' skin. As a result, diseases were common and could be devastating as the boats were often miles away from inhabited areas. Lacerations from the mollusk shells and from simply working in such a moist environment were common and could easily become infected. The men on the boats suffered from dehydration and malnutrition. Divers had the added challenges of being in and on the water at various depths for long periods of time, which resulted in punctured eardrums, skin lesions, and blindness. Moreover, the Gulf is a vibrant ecosystem with jellyfish, sharks, urchins, and coral, all of which provided their own hazards that made pearl acquisition difficult. ${ }^{17}$ Although there are no reliable statistics to show how many men fell ill during a season or whether the hazards were greater in one season than another, these trials contributed greatly to the crewmen's suffering during the pearl diving season. The stories of the dangers of pearling are very common and the narrative of suffering suffuses most divers' accounts, illustrating the idea of the pearl's tyranny in littoral life.

Interestingly, despite its beauty, the pearl was rarely used locally in the lower Gulf. There are

\footnotetext{
17 Abd al Rahman, "Rihlat al-Ghaus 1," 22-27; Hamdi Nasr, "al-Ghaus fi 'I'amaq al-Ghaus," 36-41; Hamdi Nasr, "alYaryur al-'Ams Yakhaf min al-Yaryur al-Yaum” [The shark of yesterday is afraid of the shark of today], Turath no. 95 (October 2006): 18.
} 


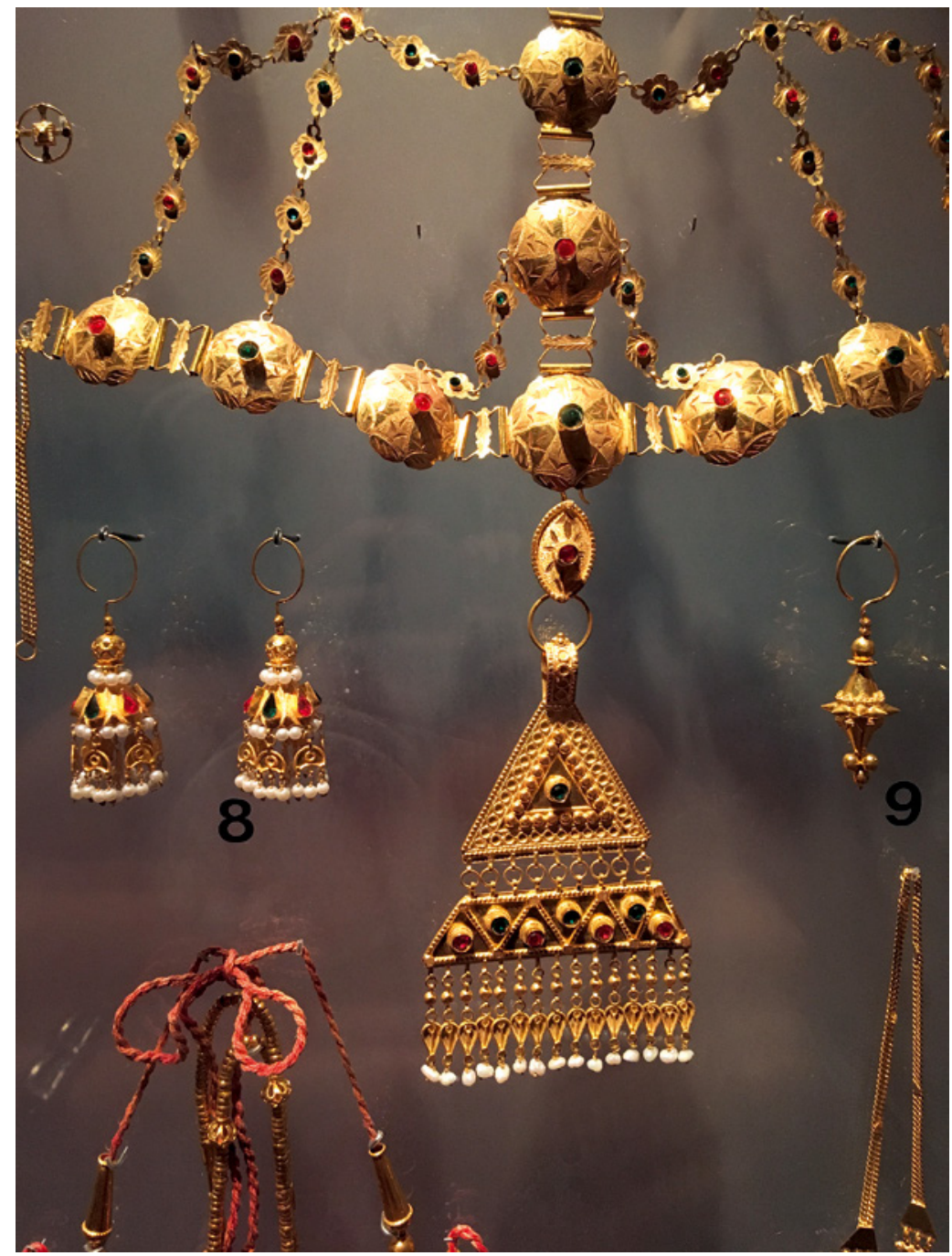

FIGURE 2.1 Mid twentieth-century pearl jewelry displayed in The Sharjah Heritage Museum, U.A.E.

some accounts of pearls being crushed for skin whiteners and shimmer powders, but this practice is not well documented. ${ }^{18}$ Similarly, museum exhibits assert their use in local jewelry, such as those at the Sharjah Heritage Museum, but this practice was not largely spread (fig. 2.1). Pearls remained

18 Xavier Beguin Billecocq, Les Émirats ou la fabuleuse histoire de la Côte des perles [The Emirates: The fabulous history of the Pearl Coast] (Paris: Relations Internationales \& Culture S.A., 1995), 25. desirable objects, yet they were not "objects in [the inhabitants'] emotional lives." ${ }^{19}$ So, the question arises: why did divers put themselves through such torment to acquire an object which, in itself, was not particularly important locally? The answer is that the importance of pearls lies mainly in their trade value. ${ }^{20}$
19 Turkle, "Introduction: The Things That Matter," 5.

20 Ibid., 48 and 78 , respectively. 


\section{The Pearl as Used}

Kant argued that understanding an object is not solely based on the object's own qualities; an object is imbued with importance through its use. ${ }^{21}$ For those who used pearls for adornment, their use value was easily identified and understood: the beauty of the thing-in-itself was sufficient to define its value. Yet, as noted above, pearls were not used regularly in the lower Gulf, so their importance was mainly constructed through their ability to be traded for more useful things. The pearl enabled inhabitants in the lower Gulf to acquire wealth and, through that wealth, to purchase necessities, including better quality dates, rice, and some luxuries like cloth from India and nuts from Persia.

Unlike the traders in the upper Gulf areas, like Bahrain or Kuwait, the traders in the lower Gulf did not become wealthy by selling pearls. Many of the leading coastal families in the lower Gulf area were involved in the pearl trade in some way, but relatively few as large scale merchants or financiers. Instead, many became mired in cycles of debt that were almost impossible to escape from, particularly as the pearl markets fluctuated dramatically in the late nineteenth century. These economic shifts reinforced a damaging cycle of debt for many families. ${ }^{22}$

The period between the extraction of the pearl, its manufacture, its sale, and the return of the profits to the lower Gulf emirates could take a full year in some cases, making it necessary for merchants to rely on advances and loans. Often, the pearl boats left for the summer diving season before the merchants returned with the profits from the previous year. Merchants, whether wealthy or

21 Colin Marshall, "Kant's Appearances and Things in Themselves as Qua-Objects," Philosophical Quarterly 63 , no. 252 (2013): 520 .

22 Victoria Penziner Hightower, "Pearling and Political Power in the Trucial States, 1850-1950: Debt, Taxes, and Politics," Journal of Arabian Studies 3, no. 2 (2013): 215-31. small-time, were not incentivized to increase profit sharing with divers because they could never be sure of their profits. ${ }^{23}$ Therefore, even in a good year, diving alone could not sustain a family. Because divers experienced agonizingly slim profit margins, ${ }^{24}$ they often supplemented their income by hunting, fishing, or trading as bad years were common.

This instability affected the local population dramatically. Dates, a dietary staple, and fresh water were imported by many on the coast, so a lack of capital meant that many people could not purchase the basic necessities of life. ${ }^{25}$ Commodity values fluctuated and, in the nineteenth century, pearl prices varied widely. Although precise values are unknown due to smuggling and underreporting, the trends were significant. We know, for instance, that pearl divers earned between 150 and 1,00o Rupees in a season, though, as noted above, the earnings could be lower. ${ }^{26}$ Between 1873 and 1896, pearl values for the lower Gulf emirates swung between a low of two million and a high of eight million Rupees in any given season. ${ }^{27}$ In the twentieth century, due to the two World Wars and the Great Depression, the values vacillated even more wildly, shifting by $30-50 \%$ between harvest

23 Frauke Heard-Bey, From Trucial States to the United Arab Emirates: A Society in Transition (Dubai: Motivate Publishing, 2004), 219; Muhammad Morsy Abdullah. The United Arab Emirates: A Modern History (New York: Barnes and Noble, 1978), 105.

24 Fahad Ahmad Bishara, A Sea of Debt: Law and Economic Life in the Western Indian Ocean, 1780-1950 (Cambridge: Cambridge University Press, 2017).

25 'Abdullah al-Shamsi, "Mihnat al-Ghaws fi al-Imarat" [The occupation of pearling in the Emirates], Majalat al-Fan wa al-Turath al Sha'abi no. 2 (June 1997): 39.

26 Man'a Sa'id al-'Otaiba, Iqtisadat 'Abu Zabi Qadiman wa Hadithan [Abu Dhabi economics past and present] (Beirut: Mutaba' al-Tijara wa al-Sina'a, 1971), 24-25.

27 Estimates taken from trade tables published in Persian Gulf Administration Reports, 1873-1947, vols. 1-4 (Gerrard's Cross: Archive Editions, 1986). 
and sale. ${ }^{28}$ This made the pearl a precarious item upon which to base an economy.

Although there are few detailed stories about how these fluctuations affected divers, there are plenty of records of how it affected merchants. In 1908, pearl merchants were forced to sell their stocks at heavy losses, which triggered a depression throughout the area. ${ }^{29}$ Some captains were so indebted that they were not permitted to sell their pearls freely; they were required to sell them only to their money lender. This constraint gave money lenders a ready supply of pearls and encouraged them to pay below the market value for the harvested pearls. ${ }^{30}$ In another period of crisis, captains continued to borrow, occasionally at outrageous rates of interest. In one case, captain Muhammad bin Ahmad Dalmuk took out a loan with a $36 \%$ interest rate to fund the 1930 season. ${ }^{31}$ Understanding how merchants were affected can

28 The following volumes are paginated-by-report: C.F. Mackenzie, "Report on Trade of the Bahrein Islands for the Year 1909," 1; J.D. Lorimer, "Report on Trade of the Bahrein Islands for the Year 1911," 6; T.C. Fowle, "Report on Trade of the Bahrein Islands for the Year Ending 31st 1916," 1; C.K. Daly "Report on Trade of the Bahrein Islands for the Years Ending 31st 1924," 1, in Persian Gulf Trade Reports 1905-1940. Bahrain I: 1905-1925 (Gerrard's Cross: Archive Editions, 1987); Cyril Charles Johnson Barrett, "Report on the Trade of the Bahrein Islands for the Year Ending 31st March 1927," 1; M. Worth, "Report on Economic and Trade Conditions on the Bahrain Islands for the Year 1933-34," 1-2; G.A. Cole, "Report on the Trade of the Bahrein Islands for the Year ending 31st March 1935," 1; Charles Jeffery Prior, "Report on the Trade of the Bahrein Islands for the Year Ending 31st March 1930," 1; E.B. Wakefield, "Amendments to Parts I and II of Mr. Wakefield's Report on Economic and Trade Conditions in the Bahrein Islands for the Year Ended 31st March, 1942," 1, in Persian Gulf Trade Reports 1905-1940. Bahrain II: 1925-1940 (Gerrard's Cross: Archive Editions, 1987).

F.B. Prideaux, "Report on Trade of the Bahrein Islands for the Year 1906," 1, in Persian Gulf Trade Reports 19051940. Bahrain I. al-Shamsi, "Mihnat al-Ghaus fi al-Imarat," 39.

31 Heard-Bey, From Trucial States to the United Arab Emirates, 219 . begin to shed light on how other parties involved in the trade experienced this instability, despite a lack of documents specific to the U.A.E.

The depressed economy affected all areas of life. By the 1940s, the economic situation was so dire that the Bedouins began eating dried, salted pearl mollusk meat, something that was particularly tough, bitter, and only eaten in case of severe nutritional emergencies. ${ }^{32}$ In an interview published in a heritage magazine, a former diver was asked how he dealt with the hunger. He answered, "by learning to live with it, the sea is treacherous and deceitful, and it teaches you patience." ${ }^{33}$ His answer illustrates the equanimity that littoral populations brought to the harvesting of pearls, but also reinforces the idea of the pearl was a tyrannical object. Pearling necessitated a significant outlay of effort and energy and it promised potential, rather than real, profits. It was an unpredictable object to base a lifestyle on and it could rarely provide a family the necessities of life.

Despite this instability, pearls represented a concrete path to material wealth. Boat culture encouraged the creation of a social order that could translate onto land. Prowess at sea embodied the ability to establish, reinforce, or change social status that transcended, or was augmented by, age, skill, and experience. The two most prestigious roles on the boat were those of the diver (ghaws) and the captain (nokhuda), and they were assigned to younger and older men as needed..$^{34}$ Most divers

Ronald Codrai, Seafarers of the Emirates: An Arabian Album (Dubai: Motivate Publishing, 2003), 65 .

33 Husayn Khamis Al Ali, "Malameh min al-Ghaus alQadim" [Glimpses of past diving], Turath no.3(1999):25. Hamdi Nasr, "al-Ghaws fi 'Imaq al-Ghaus: Saif al-Suaidi ... wa Rihla "Amar illa al-Raii Mahmal" [Diving the deepest dive: Saif al Suweidi and the command of the most beautiful ship], Turath no. 14 (2000): 38; Hamad bin Khalīfa "Abu Shihab, "al-Ghaws ... Sh'aran 2-5" [Diving ... in poetry 2-5], Turath no. 26 (January 2001): 1415; Jum'a Khalifa Ahmed bin Thaleth al Humairi, Daula al Imarat al Arabiyya al Mutahda: Rijal al Ghaws wa al Lu'lu' [The UAE: Men of diving and the pearl] (Dubai: Emirates Diving Association, 2009). 
were paired with a hauler (seeb) whose job was to pull up the diver from the seafloor. The diver/hauler pair was often assisted by other, younger men, known as radheef and tabab. The radheef was typically older than the tabab and had more responsibilities. The radheef usually helped the haulers while the tabab was more of a general apprentice on board ship, running coffee or tobacco pipes (shisha) to divers and haulers. Older men served on the pearl boats as singers (niham), cooks (tabbakh), religious scholars (mutuwa'a), bookkeepers (kuttab), shell openers (jallas), boatswains/seconds-in-command (qa'adi, sukkan), and helmsmen (mujaddami). The specialization of roles on board a ship depended on its size: the larger the ship, the more specialized the roles. On smaller ships, these roles were often combined: the captain would be a helmsman, or all divers would open shells. ${ }^{35}$

Whether the boat crew was large or small, there were significant opportunities for advancement, and this helps to illustrate how the pearl could transcend the thing-in-itself into its use value. This advancement was often not only simply occupational but also social, involving an increase in status and wealth. This was particularly true for young men. A tabab was generally seven-fifteen

35 Abdullah Abd al Rahman, "Rihlat al-Ghaws 'ala alLu'lu' min al (Madah) 'illa (al-Qufal) 1" [Pearl diving trips from the embarkation to the return 1], Turath no. 24 (November 2000): 26; Abdullah Abd al Rahman, "Rihlat al-Ghaws 'ala al-Lu'lu' min al (Madah) 'illa (alQufal) 3: al Mujaddami wa al Q'adi” [Pearl diving trips from the embarkation to the return 3: al Mujaddami and the Q'adi], Turath no. 23 (October 200o): 21; Abdullah Abd al Rahman, "Abtal Rihlat al-Ghaws 'ala alLu'lu' min al-Madah illa al-Qufal: al-Sib ... wa al-Radeef ... wa al-Tabab" [Heroes of the pearl diving trips from the embarkation to the return: al Sib and al Radeef, and al Tabab], Turath no. 25 (December 200o): 49; Al Ali, "Melameh min al-Ghaws al-Qadim" [Glimpses of pearling's past], Turath no. 3 (February 1999), 25; Ahmad Ramadan al Shaqila [Ahmad R. Thakela in English abstract], "Pearl Diving Industry in the Arab Gulf," $A$ l Khaleej Al Arabi no. 8 (1977): 37-54. years old, and a radheef was at least fourteen. ${ }^{36}$ These young men could advance within the boat's hierarchy in as little as a year or two or as much as a decade, earning more as they gained more responsibility. There were significant incentives to become more skilled. As pearls were sold, the profits were recorded and divided according to orally agreed-upon allotments. Although boat owners or captains received most of the compensation, others on board received their share of the overall profits as well. How these profits were divided depended on the year, the boat crew's level of debt, and the generosity of the boat captain or owner. ${ }^{37}$ Profits were never guaranteed, but they were always hoped for.

The instability of the profits meant that many worked to move out of the trade altogether. This is illustrated in a recollection by Abdullah bin Rashid bin Haarab al Humairi (Abu Salem), whose father, Rashid, owned four boats. One went to the pearl beds in the summer while the remainder traded goods to Africa, India, and elsewhere in the Gulf. Abu Salem recalled that his father tried to shield him from diving, bringing him on his boat, and making him a radheef or tabab. He then transferred Abu Salem from the diving boat to a trading boat. He accompanied his father on trading voyages from age 14, traveling to Dubai, Muscat, Masirah Island, Socotra, Zanzibar and back. By the

36 Abd al Rahman, “'Abtal Rihlat al-Ghaws ... al-Sib ... wa al-Radeef ... wa al-Tabab," 47-48.

37 Durand, "Appendix A," 64; Najib 'Abdullah al-Shamsi, Iqtisad al-Imarat Qabl 1971 [The economy of the Emirates before 1971] (Abu Dhabi: Muwaqifa Wizara al I'alan wa al-Thaqafa, 1995), 91; Abdullah Abd al Rahman, “Abtal Rihlat al-Ghaus ... al-Niham wa al-Mutu'a ... al-Kitub wa al-Tabakh" [Heroes of the pearl diving trips: al Niham and al Mutuwa ... al Kitub and al Tabakh], Turath no. 26 (January 2001): 20; Muhammad bin al-Samra'i, "Al-Ghaus ... bi-Haqan 'an Dhakriyyat" [Diving in real recollections], Turath no. 26 (January 2004): 16-17; Abdullah Abd al Rahman, "Rihlat alGhaws 'ala al-Lu'lu' min al (Madah) 'illa (al-Qufal) 2" [Pearl diving trips from the embarkation to the return 2], Turath no. 22 (September 200o): 67, 70. 
age of eighteen, he captained trading missions to Africa and India. ${ }^{38}$ In many ways, Abu Salem and his father typified the hope of pearling - the ability to transfer the wealth and engage in the comparatively less taxing occupation of trading.

As these accounts demonstrate, the pearl was valued less for the thing that it was and more for the economic and social value it could be used for. Its use value was in its ability to be traded. The tension between the pearl's fragility as an object, its difficult acquisition, and its revenue unpredictability makes the pearl a problematic object to integrate into a historical narrative as a laudatory object. Despite these challenges, pearling looms large in the heritage narratives in the U.A.E., providing a useful contrast to the current period of wealth and prosperity.

\section{The Pearl as Remembered}

While Kant's idea of thinghood as consisting entirely of a thing-in-itself and a thing-as-used is important, it is insufficient because an object's identity is never as fixed as Kant would have us believe. He argues that, in thinking about an object, one needs both intuition, which refers to an object directly in its singularity, and concept, which refers to an object indirectly by means of characteristics that may be common to more than one thing. ${ }^{39}$ However, both of these notions rely on a fixity of the object that is impossible given the dynamism of the memory and the past. This is where Miller's notion of "stuff" becomes so important. Miller's term considers the dialectical relationship between an object and its social and cultural importance. I am suggesting here that not only is an object's meaning created dialectically in a given time, but that, over time, an object's meaning can shift.

38 "Al Humairi Yatadhekr: Qata'a al Hasa ... wa al A'dhab al Ghaws" [Al Humairi remembers: Pieces of al Hasa ... and the suffering of pearling], Turath no. 91 (June 2006): 19-22.

Kant, Critique of Pure Reason, 193-94.
The thing-as-remembered is far from being a unitary concept so, by bringing in this notion, it is possible to understand the central challenge of the pearl as an object in the Gulf studies.

Pearls entered the U.A.E. national narrative as a cautionary tale: pearls became the means by which the Gulf emirates accessed the global economic market but also tyrannical symbols of poverty and destitution until the effective exploitation of oil. Although in some countries this contrast would result in a systematic forgetting of the past, in the U.A.E., the rapidity of change resulted in a commemoration of the past through which many heritage objects have received new lives. Sarina Wakefield and Sulayman Khalaf have discussed extensively how heritage activities like falconry and camel racing are being reinterpreted for usage in heritage narratives. ${ }^{40}$ In turn, the pearl and its luxurious connotations speak both to a national and international audience. It enables the U.A.E. to assert its identity on the global stage while also affirming the importance of its past for the national narrative. With oil profits and good management, the state's narrative promises that the suffering of the past will never be experienced again by the coastal inhabitants and this patronage has enabled the pearl to be rehabilitated and deployed within the image of luxury and progress.

This new image of the pearl has had dramatic ramifications on the heritage narrative of the U.A.E. Sarina Wakefield has discussed how the U.A.E. uses museums to assert a cosmopolitan identity, giving the decision to fund key museums, like the Louvre Abu Dhabi and the Guggenheim, as an example. ${ }^{41}$ This idea can be pushed because

40 Sarina Wakefield, "Falconry as Heritage in the United Arab Emirates," World Archaeology 44, no. 2 (2012): 280-9o; Sulayman Khalaf, "Poetics and Politics of Newly Invented Traditions in the Gulf: Camel Racing in the United Arab Emirates," Ethnology 39, no. 3 (2000): 243-61.

41 Sarina Wakefield, "Heritage, Cosmopolitanism and Identity in Abu Dhabi," in Cultural Heritage in the Ara- 
the heritage narrative has become an important part of the U.A.E.'s international branding efforts and pearling has been at the forefront of forging this narrative. In 2019, for instance, the Louvre Abu Dhabi displayed, with much fanfare, the U.A.E.'s oldest pearl (10,000 years old), which was discovered on Marawah Island. The decision to display this pearl in the Louvre Abu Dhabi was made so that the U.A.E. heritage will connect to the wider ideas of global heritage.

Heritage narratives are important for understanding the relationship between the past and the present. Jaume Franquesa argues that "heritage is not a neutral category ... but a hegemonic, ideologically loaded notion operating in interlocking social fields" that ultimately reinforces power dynamics. ${ }^{42}$ Franquesa's statement implies that there is a guided vision to transforming a thing from a thing-in-itself into a thing-as-remembered; however, there is not. Although pearls are being used to assert the U.A.E.'s role on the global stage, this effort is often not as directed or purposeful as Franquesa would have us believe. Nonetheless, the idea of pearling has clearly shifted from its nineteenth- and early twentieth-century notion of suffering.

The pearl as a thing-in-itself has been rehabilitated in recent years. Today, almost anything can have the name "pearl" associated with it-from Pearl Business Class on Etihad Airways to building names such as Dubai Pearl—to emphasize luxury and fineness. This contrasts jarringly with the memory of pearling as a difficult occupation. The narrative of past impoverishment reflects both the existing reality and an ex post facto assessment

bian Peninsula: Debates, Discourses and Practices, ed. Karen Exell and Trinidad Rico (London: Routledge, 2016), 99-116; Sarina Wakefield, "Hybrid Heritage and Cosmopolitanism in the Emirate of Abu Dhabi," in Reimagining Museums: Practice in the Arabian Peninsula, ed. Pamela Erskine-Loftus (Edinburgh: MuseumsEtc, 2013), 98-129.

Jaume Franquesa, "On Keeping and Selling: The Political Economy of Heritage Making in Contemporary Spain," Current Anthropology 54, no. 3 (2013): 347. of the past, which takes into account the postfederation wealth and prosperity of the U.A.E.

This remembrance brings together public and private sectors to invest in heritage and history, so the shifting narrative of the pearl-as-remembered becomes mutually constructed by the government and society at large. Often, this occurs through the idea of nostalgia. Michael Field attributes the rising sense of nostalgia for the past to the governmental public relations machines and ministries of information that have produced the coffee table books and inspired the magazines that are some of the sources for his study. He suggests that these works create an "image of the Gulf in the first half of this century ... of social harmony and healthy life in the date plantations and fisheries under the benign, paternalistic government of the ruling families." ${ }^{43}$ A less cynical assessment of this support comes from Christopher Davidson, a political and economic historian of the U.A.E., who explains that traditional industries in the U.A.E. are "in a relatively better position than in most other parts of the developing world, mostly due to strong government backing, a strong interest generated by tourism, and a local culture that values history and tradition." ${ }^{44}$ This investment in heritage, which is made clear in the Vision 2021 and Centenary Vision 2071, two guiding documents for the U.A.E. government, suggests that the past has an instrumental role in the present and future of the country.

Thus, the pearl is used for more than selling a luxurious lifestyle: it is an important marker of national heritage that helps reinforce the current prosperity by illustrating for people the alternative. An example of how pearling has been rehabilitated and how the ideas of luxury and tyranny are combined in its narrative is presented through

\footnotetext{
43 Michael Field, The Merchants: The Big Business Families of Arabia (London: John Murray, 1984), 178.

44 Qtd. in Gureni Lukwaro, "Traditional Industries in Decline," The National, February 27, 2010, http://www.thenational.ae/apps/pbcs.dll/article?AID=/20100227/BUS INESS/702279894\&SearchID=73387957389.
} 
the case of the diving clubs. Diving clubs and individuals who dive as a way to connect with the past are not uncommon. In the Emirates, some heritage groups send out ships for individuals to experience pearl diving without the help of modern breathing apparatus to simulate diving as it was a century ago. In Kuwait, the Kuwait Sea Sports Club's Pearl Diving Heritage Revival Festival received a good deal of coverage in August 2009, when they sent to sea 184 Kuwaiti men between the ages of fourteen and twenty to experience pearling life. ${ }^{45}$ The festival has been held periodically since the late 1980 os and, in 1995, the U.A.E. team won this event. ${ }^{46}$ During the event, the participants mentioned the feeling of connection to their heritage. One of them noted that "experiencing the hardships that our grandfathers had to bear is part of the experience" as he was explaining the sinus problems that arose out of repeated dives into the sea. ${ }^{47}$ In the U.A.E., the Emirates Maritime Environmental Group held a pearl diving event in 2009, and the Emirates Heritage Club periodically does the same. On these events, individuals are invited to go onto the pearl boat to directly "experience" the life of a pearl diver or a hauler. ${ }^{48}$

45 James Calderwood, "Return of the Pearl Divers," The National, August 12, 2009, http://www.thenational.ae/ apps/pbcs.dll/article?AID=/20090812/FOREIGN/70811 9846\&SearchID=733879577908.

“U.A.E. Team Wins Pearl Diving Championship," Khaleej Times, September 6, 1995. Ibid.

48 For other initiatives by local foundations or tourism agencies, see, for instance, "Embrace Arabia," Abu Dhabi Pearl Journey, 2015, http://www.adpearljourney. com/; and "Ajman Offers Pearl Diving Journey," Gulf News, January 5, 2018, https://gulfnews.com/business/ tourism/ajman-offers-pearl-diving-journey-1.2152119. It is worth noting that, in addition to diving clubs, hotels offer diving to tourists as well, as a way to experience the Emirati past. Although not government-directed, they support the government's desire to show the dramatic growth of the state in the past century and to
These events have important benefits. They vividly demonstrate the difficulties of the pearl trade in the past, an aspect that is largely lost to contemporary Emiratis. They also give the participants useful insight into the pearling experience and increase their degree of sympathy for, empathy with, or respect for past populations that made a living from this practice just fifty years ago, creating connections that could otherwise be ignored or forgotten entirely. However, these events offer only a version of the past experience rather than a genuine immersion in it. First, the participants do not depend on pearls for their yearly income and the pearls they do or do not find are not the difference between life and starvation. Second, the compulsion to push to exhaustion is also missing. Third, like all living history projects, it is impossible to create the full effect of life on board the ships because the "crew" is not going to sleep on board for months on end, they do not have to fish for their sustenance, and they can return to shore, hot baths, plentiful food, and relative comfort at the end of the experience. Furthermore, participants are not taught from a young age that this is their only means of earning most of their income for the year, nor do they work their way up from tabab to diver to captain. They often begin at the role of diver or hauler, without experiencing the slow growth of skills and status.

With rare exceptions, diving for pearls is no longer an occupation in the twenty-first century. Pearl diving is almost entirely a heritage activity undertaken by men to connect with their family's past, their national history more broadly, or to engage in tourist activity. The hardship associated with the practice of pearling has been turned into a point of pride, a narrative of having survived and surmounted the challenges of the past. This nostalgic look at the pearl does not shy away from the idea of the pearl as an oppressive or tyrannical object; rather, it rehabilitates it into a narrative of survival

connect the U.A.E. to a global audience ready to consume history and reinforce the state's legitimacy. 
that empowers the contemporary nation while telling its story to the world.

\section{Conclusion}

The pearl is not simply a piece of jewelry in the U.A.E. today. As a material object, it is fraught with painful and hopeful memories. In the nineteenth century, the pearl enabled access to the global market and provided a source of income for many on the Arabian coast. It provided the coastal inhabitants with a way to access goods that could diversify their diets or improve their material lives. As an object, the pearl was a luxury item; however, it was far from being something so simple for the Gulf inhabitants, for whom it was a means of survival and access to regional and global commodities. The value of the pearl helped to create a connection to the object. The pearl-as-remembered is bound with the national project of developing the Emirates and with the notion of identity formation. It has entered the commercial and heritage lexicon as an iconic symbol of a past of struggle and a future of boundless prosperity. The tyranny of the pearl is expressed through the tension between its reality, value, and memory, between the thing-in-itself, -asused, and -as-remembered. It is a symbol of the good and the bad of the past that highlights the benefits and greatness of the present. 